\title{
PowerLab system experimentation and medical students \\ enhances learning in physiology pre-clinical
} PowerLab sistemi preklinik tıp fakülttesi öğrencilerinde
fizyoloji deneylerini ve öğrenmeyi kolaylaştırmaktadır

Terkuma Chia ${ }^{1, *}$, Oluwatosin IImoleayo Oyeniran²

${ }^{1}$ Department of Anatomy, Faculty of Basic Medical Sciences, College of Health Sciences, Nile University of Nigeria, Abuja, Nigeria. ${ }^{2}$ Department of Physiology, Faculty of Basic Medical Sciences, College of Health Sciences, Nile University of Nigeria, Abuja, Nigeria.

Corresponding author: Terkuma Chia, MD, Department of Anatomy, Faculty of Basic Medical Sciences, College of Health Sciences, Nile University of Nigeria, Abuja, Nigeria.

E-mail: terkumachia@hotmail.com

Received/Accepted: January 28, 2020 / October 27, 2020

Conflict of interest: There is not a conflict of interest.

\section{SUMMARY}

Objective: Data acquisition systems (DAQ) such as PowerLab system find wide applications in teaching and research. The aim of this study is to evaluate how the use of PowerLab system enhances physiology experimentation and learning in pre-clinical medical students.

Method: This study was carried out among 55 pre-clinical medical students of Nile University of Nigeria, Abuja. A pre-tested self-administered questionnaire was used to investigate their awareness and perceptions on the use of PowerLab system in teaching and conducting Physiology experiments. The data were entered and analyzed using Microsoft Excel version 2016 for Windows. Frequency distribution and summary statistics were analyzed by descriptive analysis.

Results: Fifty-five $(n=55)$ out of 90 pre-clinical students participated in this study, with an overall response rate of $61.1 \%$. Fifteen $(27.3 \%)$ respondents were males and $40(72.7 \%)$ were females, with a mean age of 18.5 years. More than $90 \%(\geq 50)$ of the respondents agreed to be aware of PowerLab system, and that it has been used to teach and demonstrate several experiments to them. On the perceptions of respondents to the use of the system; majority affirmed that it enhanced their understanding of the experiments $(n=43 ; 78 \%)$, stimulated imagination and critical thinking skills $(n=35 ; 64 \%)$ and helped them learn physiological concepts better than conventional methods $(n=47 ; 86 \%)$.

Conclusions: The use and application of computer-based data acquisition devices such as PowerLab system provide students with hands-on and state of the art exposure to current research trends in medical sciences and are now indispensable tools for medical education.

Keywords: Medical students, PowerLab, physiology, research, learning
Terkuma Chia

Oluwatosin Imoleayo Oyeniran

ORCID IDs of the authors: T.C. 0000-0002-3257-459X O.I.O. 0000-0001-6720-8453 
Amaç: PowerLab sistemi gibi veri toplama sistemleri (DAQ) öğretim ve araştırmada geniş uygulamalar bulmaktadır. Bu çalışmanın amacı, PowerLab sisteminin kullanımının klinik öncesi tıp öğrencilerinde fizyoloji deneylerini ve öğrenmeyi nasıl geliştirdiğini değerlendirmektir.

Yöntem: Bu çalışma Abuja, Nijerya Nil Üniversitesi'nde 55 klinik öncesi tıp öğrencisi arasında gerçekleştirildi. Fizyoloji deneylerinin öğretiminde ve yürütülmesinde PowerLab sisteminin kullanımına ilişkin farkındalıklarını ve algılarını araştırmak için önceden test edilmiş kendi kendine uygulanan bir anket kullanıldı. Veriler, Windows için Microsoft Excel sürüm 2016 kullanılarak girildi ve analiz edildi. Tanımlayıcı analiz ile frekans dağılımı ve özet istatistikler analiz edildi. Bulgular: Klinik öncesi 90 öğrenciden 55'i $(\mathrm{n}=55)$ bu çalışmaya\% 61.1 genel yanıt oranıyla katıldı. Ankete katılanların 15 'i (\% 27,3) erkek, 40'ı (\% 72,7) kadındı ve yaş ortalaması 18,5 idi. Ankete katılanların\% 90'ından ( $\geq 50)$ fazlası PowerLab sisteminin farkında olduğunu ve onlara birkaç deney öğretmek ve göstermek için kullanıldığını kabul etti. Katılımcıların sistem kullanımına ilişkin algılarına göre; Çoğunluk deneyleri anlamalarını geliştirdiğini ( $\mathrm{n}=43 ; \%$ 78), hayal gücünü ve eleştirel düşünme becerilerini $(\mathrm{n}=35 ; \%$ 64) uyandırdığını ve fizyolojik kavramları geleneksel yöntemlerden daha iyi öğrenmelerine yardımcı olduğunu ( $\mathrm{n}=47 ; \% 86)$ ifade etti.

Sonuç: PowerLab sistemi gibi bilgisayar tabanlı veri toplama cihazlarının kullanımı ve uygulaması, öğrencilere tıp bilimlerindeki güncel araştırma eğilimlerine uygulamalı ve son teknoloji ürünü bir bakış açısı sağlar ve artık tıp eğitimi için vazgeçilmez araçlardır.

Anahtar sözcükler: Tıp Öğrencileri, PowerLab yazılımı, fizyoloji, araştırma, öğenme

\section{INTRODUCTION}

The use of computer-based data acquisition systems in life and biomedical sciences have widely substituted antique oscilloscopes, kymographs, chart recorders, and polygraphs resulting from its' ease of use, cost, size, care and consumables; and have been reported to enhance contextual learning of basic scientific concepts ${ }^{1-}$ 6. The PowerLab system developed by AD Instruments; Sydney, Australia, is a studentcentred, data acquisition and analysis system. This system is useful for simulating physiological experiments thereby making teaching easier by combining many processes into one program which includes; real-time data acquisition, data analysis, report completion and submission amongst others 7-9.

Recent increases in enrolments of prospective students into medical school yearly have led to large class sizes. The resultant effects have justified the need to utilize sophisticated teaching aids, to enhance quality teaching and efficient lesson delivery in the classrooms and laboratories $[5,6,10$ 12]. Teaching complex biological processes to undergraduate medical students can be complex. This may be attributed largely to insufficient time, inadequate resources, and little or no skilled manpower and technical know-how, especially in low-resource settings ${ }^{1}$.

Physiology teaching, most importantly laboratory exercises and experiments in the undergraduate curriculum of many medical schools has developed substantially in recent times due to the introduction of computer-based data acquisition system (DAQ) and availability of simulated software ${ }^{2-4}$. With the aid of this system, medical students can design experiments, apply the protocols, and evaluate the results if encouraged and given a framework ${ }^{13}$. The aim of this study is to evaluate how the use of PowerLab system enhances physiology experimentation and learning in pre-clinical medical students of Nile University of Nigeria, Abuja.

\section{MATERIAL AND METHODS}

This descriptive cross-sectional study was carried out among pre-clinical medical students of Nile University of Nigeria, Abuja; a newly established medical school. The total population of secondyear (Year-II) and third-year (Year-III) medical students within the study period (2018/2019 academic session) was 90 . To recruit participants for the study, convenience cluster sampling (a nonprobability statistical sampling method) was used in which the whole students who were qualified and willing to participate in the study were included. Following informed consent, fifty-five (55) pre-clinical medical students representing a response rate of $61.1 \%$ volunteered to participate in the study. All the respondents completed and submitted their surveys indicating a $100 \%$ compliance rate. The duration and period of study was 3 months and between July and September 2019 respectively.

A self-designed questionnaire was used to carry out the study. Its development involved an initial preparatory phase, a pilot study phase, and a final revision phase. During the preparatory phase, we performed a rigorous literature search and revised available published studies concerning the use of PowerLab system for teaching and conducting 
physiology experiments. We then designed a simple questionnaire to evaluate how the use of PowerLab system enhances physiology experimentation and learning in pre-clinical medical students. The questions on students' perceptions were scored using a five-point Likert scale ranging from 1 to 5 .

The significance of each included question and the overall inclusion of the applicable aspects necessary for the study were thoroughly reviewed. Next, we conducted a pilot study on 5 medical students to check the consistency of the questionnaire. Any vague or confusing items were modified appropriately. The final revision was then used in the primary study. The data were entered and analyzed using Microsoft Excel version 2016 for Windows. Frequency distribution and summary statistics were analyzed by descriptive analysis.

\section{RESULTS}

\section{Socio-demography of study participants}

Fifty-five ( $\mathrm{n}=55)$ out of a total of 90 pre-clinical students consented and participated in this study, with an overall response rate of $61.1 \%$. Fifteen (27.3\%) respondents were males and 40 (72.7\%) were females. The mean age of the participants was 18.5 years (age range of $15-25$ years).

\section{Students' awareness of using PowerLab system for learning and conducting Physiology experiments}

When asked if they were aware that the PowerLab system is a biological data acquisition machine and that it is used for learning and conducting physiology experiments; 51 (92.7\%) respondents agreed, while only 4 (7.3\%) disagreed. Regarding whether PowerLab system has been used in the physiology laboratory to demonstrate any physiological experiments to them, $96.4 \%$ of the respondents $(n=53)$ agreed, while $3.6 \%(n=2)$ of the participants disagreed.

To further assess the students' awareness to the use of PowerLab system for physiology experimentation and learning; they were asked if it has been employed to learn or demonstrate any scientific concepts, 52 out of 55 respondents representing $94.5 \%$ affirmed, while the remaining $3(5.5 \%)$ respondents didn't affirm to the inquiry. Concerning using the PowerLab system to conduct any physiology research work either individually or as a group, $21(38.2 \%)$ students agreed to have used it, while $34(61.8 \%)$ students haven't used it to conduct any research work.

Some of the experiments conducted by the students using PowerLab system include; electroencephalography (EEG) studies, electromyography (EMG) and muscle strength test, graded responses and muscle fatigue in skeletal muscles amongst others.

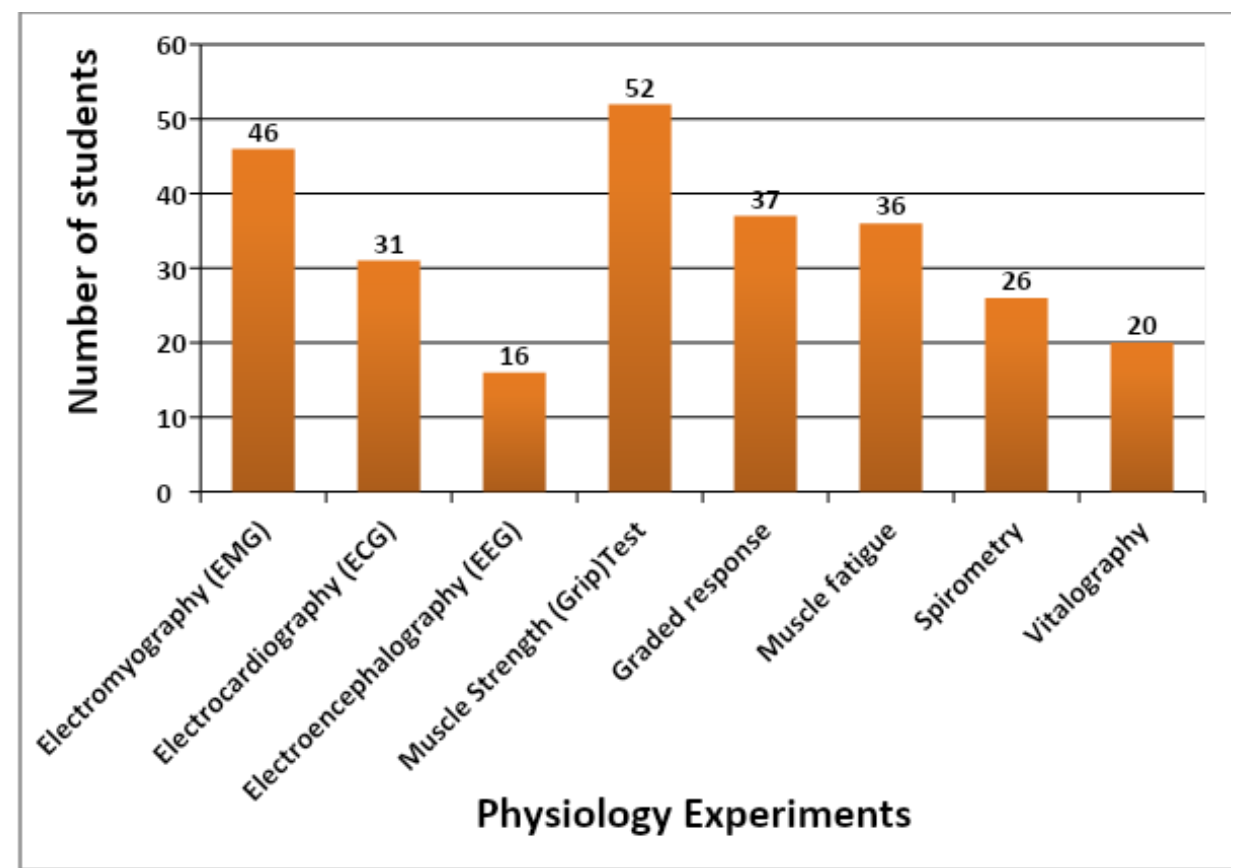

Figure 1: Physiology experiments learnt and demonstrated using PowerLab system 
General perceptions of students to the use of PowerLab system for learning and conducting Physiology experiments

The perceptions of the respondents to the use of PowerLab system for learning and conducting physiology experiments were obtained. More than half of the students agreed that this data acquisition system; enhances their understanding of the various experiments $(n=43)$, is easy and fun to use $(n=41)$, stimulate their imagination and critical thinking skills $(\mathrm{n}=35)$, and help them learn physiological concepts $(n=47)$ better than traditional methods of demonstrating physiology experiments (Table 1).

Other perceptions obtained from the students' use of PowerLab system in this study suggests that it is: unique, efficient, effective, and easy to handle; display visual representation of data and enhances better comprehension and knowledge of physiology experiments and concepts.

Table 1: Perceptions of medical students to the use of PowerLab system for teaching Physiology experiments

\begin{tabular}{|l|l|l|l|l|}
\hline \multirow{2}{*}{ Variables } & \multicolumn{2}{l|}{ Responses } \\
\cline { 2 - 6 } & \multicolumn{2}{l|}{ Agreed } & \multicolumn{2}{l|}{ Disagreed } \\
\cline { 2 - 6 } & Number & Percentage (\%) & Number & Percentage (\%) \\
\hline Enhance understanding of the experiments & 43 & 78.2 & 12 & 21.8 \\
\hline Stimulate imagination and critical thinking & 35 & 63.6 & 20 & 36.4 \\
\hline Easy and fun to use for experiments/research & 41 & 74.5 & 14 & 25.5 \\
\hline Help to learn physiological concepts better & 47 & 85.5 & 8 & 14.5 \\
\hline
\end{tabular}

\section{PowerLab system enhances the understanding of Physiology experiments}

The degree of students' understanding of the various experiments conducted and taught using the PowerLab system were evaluated. The data obtained from this finding showed that most of the experiments demonstrated using this data acquisition system was well understood and comprehended by many of the study participants. Using the Likert scale to ascertain the degree of understanding, $50(91 \%)$ students had a good to excellent level of comprehension as shown in Figure 2.

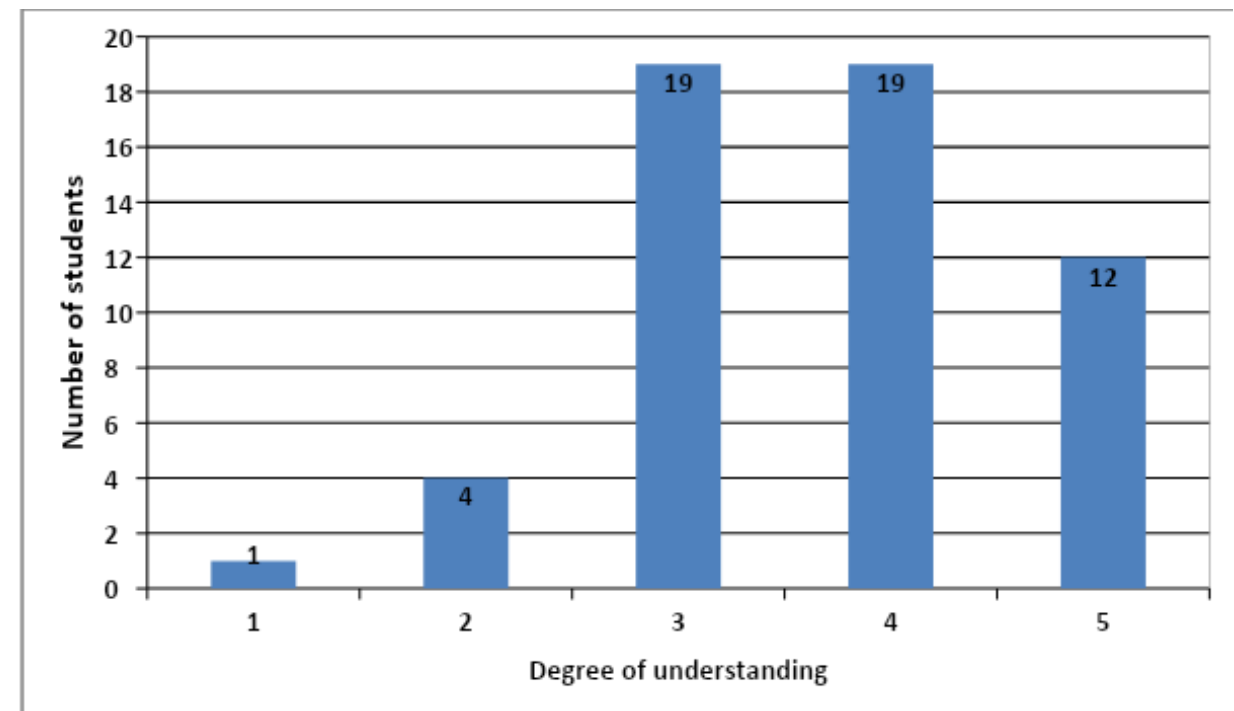

Figure 2: Degree of understanding of the experiments conducted using PowerLab system *1=Fair; 2=Average; 3=Good; 4=Very Good; 5=Excellent 


\section{PowerLab system stimulates students' imaginative and critical thinking skills}

The use of PowerLab system helped in stimulating the imagination and critical thinking skills of students during their physiology experiments. According to the Likert scale, 39 (71\%) respondents had a good to excellent degree of stimulation and excitement as shown in Figure 3.

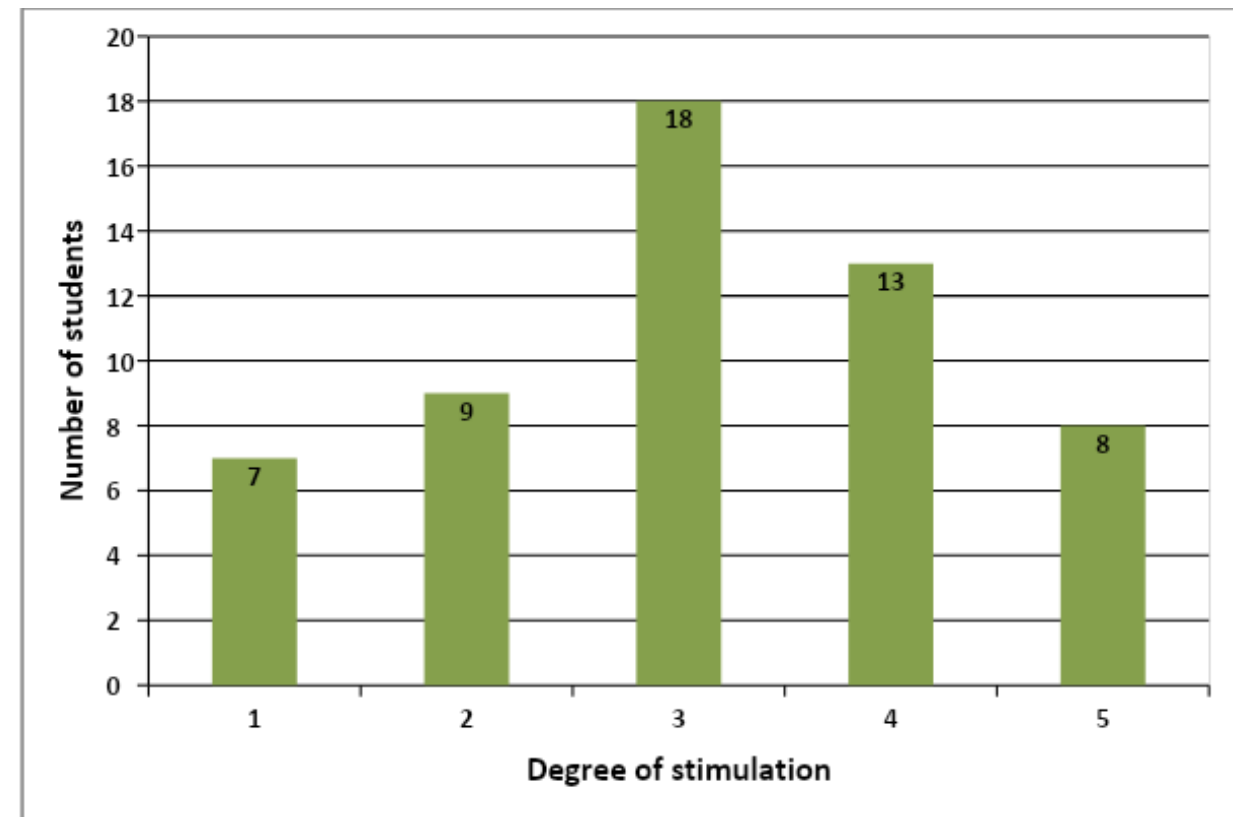

Figure 3: Degree of stimulation of students' imagination and critical thinking skills

*1=Fair; $2=$ Average; $3=$ Good; 4=Very Good; 5=Excellent

\section{PowerLab system enhances the learning of physiological concepts during experiments}

The level at which the use of PowerLab system enhanced students' learning of physiological concepts was also assessed. Results from our findings showed that the use of this data acquisition system in learning and conducting of physiology experiments enabled the respondents to learn certain physiological concepts and experiments better than the use of existing traditional methods. Using the Likert scale, $45(82 \%)$ respondents showed a good to excellent degree of learning and understanding of physiological concepts during experiments as displayed in Figure 3.

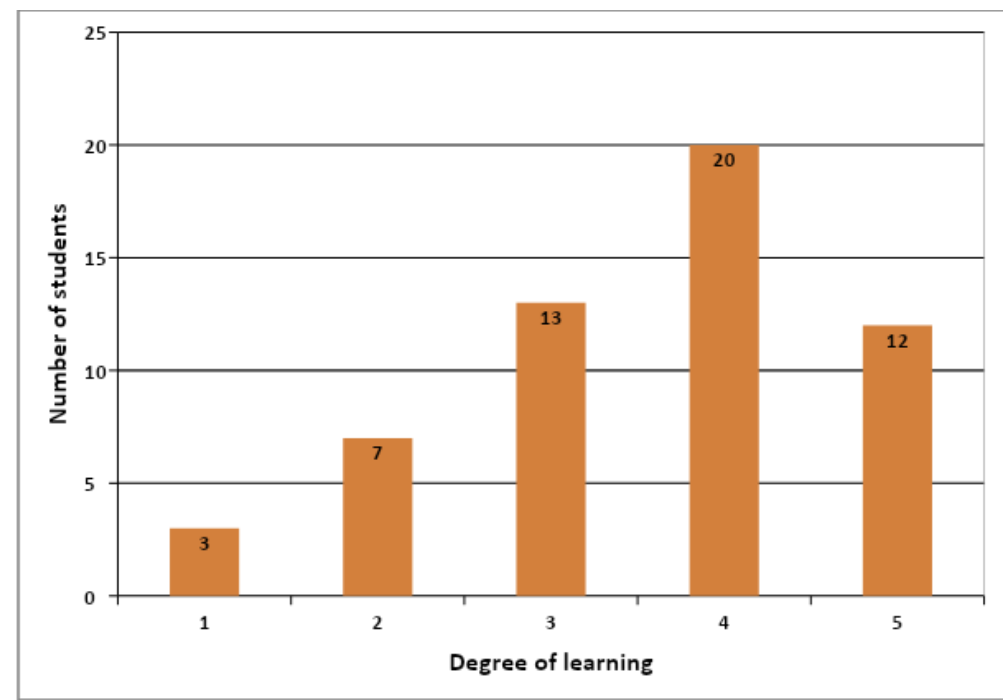

Figure 4: Degree of students' learning of physiological concepts

$* 1=$ Fair; $2=$ =Average; $3=$ Good; 4=Very Good; 5=Excellent 


\section{PowerLab system ease of use boost students' engagement in physiology experiments}

When the respondents were asked on the ease of use of the PowerLab system, majority of them agreed that it is easy, convenient, and fun to use. The Likert scale also indicated that $45(82 \%)$ students were able to handle and use the system with a good to excellent degree of ease. They also admit deriving fun when using the system, which in turn increase students' engagement and application of the PowerLab system in learning and experimentation.

\section{DISCUSSION}

There is a long history in the use of traditional and conventional approaches to conducting physiology experiments and researches. However, in recent times novel developments in data recording systems for medical sciences have evolved, thereby raising the need for introduction of these systems for teaching and research purposes in medical schools, especially in low-income and resource countries.

Our findings showed that there was a high level of awareness of PowerLab data acquisition system among our pre-clinical medical students, as about $93 \%$ of them agreed to be aware and conversant with the equipment. Though, there are no studies that have reported students' awareness of the use of PowerLab system, few studies ${ }^{2,8}$ have used it to teach physiology courses to medical students. This current study also reveals that in addition to using the PowerLab data acquisition system to teach students, over $38 \%$ of the respondents confirmed to have used it to carry out physiology research work either individually or as a group. This report is supported by the recommendation of a study, which states that students tend to take greater interest in their experiments and researches using computers, as this encourages independent learning 13 .

Evidences from this present study also suggest the usefulness of data acquisition system in conducting physiology experiments. In our findings, $96.4 \%$ of the students affirmed that PowerLab system was used to demonstrate several scientific concepts with accurate and reliable results, which in turn enhanced better understanding of the experiments, compared to when the traditional methods were employed. This report agrees with several studies where PowerLab system was used to demonstrate and teach; audiometry experiment 8 neuromuscular, reflex, and cardiovascular physiology experiments ${ }^{2}$. The advantages of using the PowerLab system over the traditional methods of conducting and teaching physiology laboratory experiments are enormous. The PowerLab teaching system consist of suites of pre-prepared (simulated) experiments modified to suit your specific curriculum needs, provides self-guided and selfpaced learning experiences, and requires minimal experimental set-up amongst others. The software (LabChart) used by the system is superb, as it allows students to edit, analyze, and print their data. However, the issue with this equipment is cost: the cost for multiple PowerLab 4/25 teaching system currently stands at between $\$ 13,000$ $\$ 15,000$ (AD Instruments; Sydney, Australia).

From our findings in this study, the respondents had a better perception about the use of PowerLab system for physiology experiments. Over $70 \%$ of the students agreed that the system was easy to operate and that they derived fun from its use and application. This report is in concord with a study which states that PowerLab system has userfriendly software, making it ideal for teaching and research ${ }^{13}$. In addition, majority of the respondents $(\geq 40)$ attested that the use of PowerLab system helped in enhancing their understanding of various physiology experiments that was conducted and played a pivotal role in assisting them to learn physiological concepts better, a positive perception level of $78 \%$ and $85 \%$ respectively. These results agreed with previous studies which supported the effectualness of computerized data recording system in self- and directed-learning, drive and better performance and skills development in undergraduates' courses of several scientific disciplines ${ }^{8,9,13}$.

Evidence from classroom and laboratory assessment increasingly supports that the effective use of computer-based systems such as PowerLab may stimulates students' imaginative and critical thinking skills ${ }^{8,13}$. Similarly, data obtained from this present study indicates that 35 students (64\%) out of the overall respondents agreed that the use of PowerLab system excited their imagination and critical thinking abilities.

Worthy of note is the invaluable role that the PowerLab system had played in Physiology teaching and research in our university since the inception of its use. This system had been used to record and analyse different human and animal physiological parameters including, blood pressure, pulse rate, temperature, electrocardiograms, respiration, electroencephalograms, electromyograms, muscle and nerve activity amongst others. The recording and analysing of the above parameters enables our students learn about the normal physiological 
functions of the human body system, likewise being important in comprehending the various changes that happen during disease conditions.

Furthermore, the use of the PowerLab system have substantial effects on the scientific overview of the students and their future careers as physicians and healthcare professionals. Its' use for learning and scientific research by pre-clinical medical students creates a beneficial experience outside paper publication or research presentations. It helps to advance understanding of diagnostic procedures and laboratory-based examinations. Regarding the future careers of students, the use PowerLab for learning and research purposes could boost the competitiveness of medical students for residencies after graduation, as the necessary skills needed for better charting and clinical note taking are learnt through research practices. More so, a research experience during undergraduate medical training is instrumental for medical doctors who aspire to become researchers, partner with or encounter researchers during their medical practice. A good understanding of suitable experimental design, procedures, analysis, writing and presentation can greatly augment their future endeavours and collaborations in science and medicine.

The limitation of the present study is that the findings could not be generalised for the whole preclinical medical students, as the questionnaires were only served to second- and third-year medical students of Nile University of Nigeria in an academic session, without involving students from other academic sessions and those from other universities. Further studies to assess the perceptions of medical students in other academic sessions and universities should be conducted in the future for comparisons.

\section{CONCLUSION}

The use and application of computer-based data acquisition devices such as PowerLab system in physiology teaching and research is gradually increasing and gaining momentum, even in middleand low-income countries such as Nigeria. These systems furnish medical students with hands-on and state of the art exposure to current research trends in the basic medical and life sciences and are now indispensable tools for quality medical education globally.

\section{Source of Funding}

This research did not obtain any grant or financial support from funding agencies in the public, commercial, or not-for-profit sectors.

\section{Conflict of Interest}

The authors have no conflicts of interest to declare.

\section{Ethical Approval}

The ethical approval for this study was obtained from the Ethical Review Board of the Nile University of Nigeria, Abuja. The study was conducted in accordance with the Declaration of Helsinki.

\section{Consent}

The aim of the research was well explained to the participants and informed consent was duly obtained from them.

\section{Authors' contributions}

OIO conceived and designed the study. TC conducted the research and provided research materials. All authors collected, organized, analyzed and interpreted data. All authors wrote initial and final draft of article and provided logistic support (where necessary). All authors have critically reviewed and approved the final draft and are responsible for the content and similarity index of the manuscript.

\section{Acknowledgement}

The authors acknowledge the management of Nile University of Nigeria, Abuja for giving us the permission to carry out this research.

\section{REFERENCES}

1. Samsel RW, Schmidt GA, Hall JB, Wood LD, Shroff SG, Schumacker PT. Cardiovascular physiology teaching: computer simulations vs. animal demonstrations. Adv Physiol Educ. 1994; 266(6): S36-S46.

2. FitzPatrick KA. An investigative laboratory course in human physiology using computer technology and collaborative writing. Adv Physiol Educ 2004; 28(3): 112-119.

3. Lewis MJ. Computer-assisted learning for teaching anatomy and physiology in subjects allied to medicine. Med Teach. 2003; 25(2): 204-207.

4. Rawson RE, Quinlan KM. Evaluation of a computer-based approach to teaching acid/base physiology. Adv Physiol Educ. 2002; 26(2): 85-97.

5. Kittnar O, Vavrova M, Trojan S. Computeraided physiology (teaching, learning and research). Physiol Res. 1991; 40(5): 549-553.

6. Farrell AP, Bruce F. Data acquisition and analysis of pulsatile signals using a personal computer: an application in cardiovascular physiology. Comput Biol Med. 1987; 17(3): 151159. 
7. George S. Data acquisition and display for electrophysiology: PC oscilloscopes. J Undergrad Nuerosci Educ. 2006; 5(1): R11-R14.

8. Penhaker M, Kijonka J. Audiometry for Teaching Experiment in PowerLab Systems. In Electrical Power Systems and Computers 2011 (pp. 831-838). Springer, Berlin, Heidelberg.

9. Marsden SP, Boddy IJS, Strachan RD, Chambers IR. In-house development of a dedicated data acquisition and monitoring system for intracranial pressure, patient posture and patient symptoms in a regional neurosciences centre. Physiol Meas 2016; 37(2): N1.

10. Stone DN, Dujardin JP. Efficient use of a digital oscilloscope-computer combination in the physiology laboratory. Comput Biol Med. 1982; 12(2): 143-147.

11. McAteer E, Neil D, Barr N, Brown M, Draper $S$, Henderson F. Simulation software in a life sciences practical laboratory. Comput Educ, 1996; 26(1-3): 101-112.

12. Young SS. Computerized data acquisition and analysis for the life sciences: a hands-on guide. 1st ed. New York, USA: Cambridge University Press; 2001.

13. Simonetta G, Aziz N, Forrester K. Recent developments in data recording systems for Physiology. Pak J Physiol, 2006; 2(1): 34-37. 